\title{
PUBLIC AUTHORITIES IN UNDERDEVELOPED COUNTRIES
}

\author{
A. H. Hanson*
}

\section{r. Enterprise and Development}

The non-communist underdeveloped countries provide an extraordinarily rich but as yet poorly-exploited field for the comparative study of public enterprise. It is not that they have shown any special capacity for institutional invention; on the contrary, the forms of public enterprise they have adopted are invariably copies from the West. The British public corporation, for example, has been extremely influential; the state company and the "mixed" enterprise, characteristic of Western Europe, has been widely imitated; Tennessee Valley Authority-type enterprises have appeared wherever river valleys offer the possibility of multi-purpose development. Part of the interest of these experiments for the political scientist lies precisely in the problems encountered in the transplantation of institutions. Western forms of public enterprise, placed in an alien and underdeveloped setting, inevitably display characteristics quite untypical of their prototypes-to such an extent, indeed, that the question often arises whether the attempt at imitation was well-advised. There is an even greater interest in the efforts of these countries to use public enterprise as one of the prime movers of economic development. When employed in this way, the public corporation of the state company has an importance far beyond that which is attached to it in the West, where "nationalized industries" have appeared at a comparatively late stage in the developmental process and have often been presented as an alternative, to be accepted or rejected principally on ideological grounds, to a private entrepreneurship which has already by its own efforts raised the economy to a level of considerable affluence. In many of the less developed countries, in fact, public enterprise presents itself not so much as an alternative to private enterprise as a substitute for it. Where private entrepreneurship is weak, where capital is scarce, and where privately-owned investable funds tend to flow into developmentally neutral channels, development through public enterprises appears a matter of necessity rather than of choice. Hence the "socialistic" appearance of the economies of new countries, such as Pakistan, which certainly have no ideological leanings towards a "socialist pattern of society."

- B.A. 1934, M.A. I946, Oxford University. Reader in Public Administration, University of Leeds; currently Research Fellow, Nuffield College, Oxford, England. Served as consultant in Turkey and India, under the auspices of the United Nations and the Organization for European Economic Cooperation (O.E.E.C.). Editor, Public Enterprise, A Study of Its Organisation and Management in Various Countries (1955). Author, The Structure and Control of State Enterprises in Turiey (I959); Studies in Turkish Local Government (1955); Public ENTERprise and Economic Development (1959); Le Secteur Public dans une Economie en Voie de Développement (ig6r); Parliament and Public Ownership (196r). Contributor to periodicals on public administration and political science. 
In some countries, of course, a preference for socialist forms of economic organization does exist. India is the outstanding example. But even here the intention is not to socialize the whole of the economy, but to reserve certain parts of it (sometimes referred to, in Lenin's phrase, as the "commanding heights") for exclusive development by the public sector, while defining the respective roles of public and private enterprise in the remaining parts. As is well known, this is what the Indians have attempted to do in their two Industrial Policy Resolutions of 1948 and 1956. Elsewhere, the perspective is often a different one. The state undertakes to provide and maintain the infrastructure of the economy (e.g., communications and power) but does not envisage much permanent public participation outside this field. In the early days of economic development it may be compelled, through the lack of private initiative, to pioneer a variety of industrial, agricultural, financial, and commercial enterprises, but it hopes gradually to divest itself of these responsibilities by transferring them, as the time becomes ripe, to the private entrepreneur. The locus classicus of this type of development is Japan. The Japanese industrial expansion of the last quarter of the nineteenth century was mostly state-promoted and state-financed, but the government always sought the first opportunity to sell out its investments and to withdraw from management. ${ }^{2}$ Modern imitators of this policy have been many, Pakistan and Mexico providing two of the more conspicuous examples. In some countries it has been adopted only after the attempt to encourage the expansion of private enterprise by financial and other inducements has failed. Pakistan, for instance, took to state-promoted industrial development in 1952, when it had become clear that the cheap loans offered by her Industrial Finance Corporation were failing to stimulate private entrepreneurship to any marked degree. 'Turkey went over to the policy of "étatisme" in the r930's, partly as a consequence of the private sector's lack of response to her Law for the Encouragement of Industry. In both cases some industrial development has been achieved, but in respect of the second, "selling out" stage, there is a sharp contrast. In Pakistan, considerable private capital has been introduced into state-promoted enterprises," and some of them have been completely turned over to the private sector; but in Turkey all the enterprises founded during the I930's remain in the hands of the state and many new ones, entirely state-owned and state-managed, have been subsequently added. Up to I950, the failure to attract private capital was to some extent deliberate, as the ruling People's Republican Party had a principled if somewhat vague commitment to public enterprise; but during the period of office of

\footnotetext{
${ }^{2}$ See Indian Planning Commission, The First Five Year Plan (r952), The Second Five Year PLAN 29-30, 43-50 (1956).

${ }^{3}$ See William W. Lockwood, The Economic Development of Japan, Growth and Structural Change i868-I938, at 503-09 (r954).

${ }^{3}$ See II Government of Pakistan, The First Five Year Plan 218 (I956).

- See A. H. Hanson, Mümtaz Soysal \& Gülgun Gönenç, The Structure and Control op State ENTERPRises in Turkey 6, 7 (2d ed. 1959).

${ }^{5}$ See infra, at 627-28.
} 
the Democratic Party (1950-60), the situation was that the government wanted to sell out but could not do so for want of buyers. ${ }^{6}$

The Turkish example, and many other similar examples, prove that the "pumppriming" view of public enterprise does not always work out. Whether it likes it or not, the state may well find itself more or less permanently responsible for a collection of enterprises over and above those which, because of their basic character, are scheduled for retention in the public sector. It is not, therefore, only in the socialistically minded countries that the problems of controlling and managing such enterprises can become acute.

\section{Institutions}

These problems are frequently discussed in a way to suggest that they can be reduced to a single problem: the discovery of the "right" institutional form. No one, of course, can doubt that the ordinary government department provides a framework quite unsuitable for commercial-type operations, and that consequently something radically different from it needs to be devised. No public enterprise can work efficiently if it is subjected to standard budgetary procedures, to control of its day to day expenditures by a Ministry of Finance; and to all the personnel regulations applicable to the civil service. It will also incur serious disadvantages if it is unable to make contracts and conduct litigation in its own name and on its own responsibility. Truly businesslike operations, moreover, will hardly be facilitated if it is required to submit all but merely routine decisions to the approval of a supervisory ministry, responsible to Parliament. These disadvantages can sometimes be avoided by modifying the normal departmental structure, so as to provide the enterprise, although in law remaining part of the ordinary governmental apparatus, with certain immunities which enable it to conduct its affairs with some degree of commercial flexibility. In most cases, however, the creators of public enterprises have found clear advantage in abandoning the departmental structure and in devising entirely new institutional frameworks. Of these, the most familiar are the public corporation and the state company, whose basic characteristics are now so well known as to require no further definition or description. What is less well understood, particularly in the underdeveloped countries, is that institution-making as such solves none of the basic problems. Everything depends on the conventions that are permitted to develop within the institutional framework-in other words, on the informal relationships which can either realize the purposes of the institutions or kill them stone dead. These informal relationships, in their turn, will be influenced by prevailing social values, by the current political "style," and by the characteristic way in which the country concerned goes about its governmental business.

It is factors of this kind, rather than formal institutional arrangements, that will determine whether a public enterprise is to be a success or failure as a business organization. In the West, they are generally-although of course not uniformly-

\footnotetext{
' Hanson, Soysal \& Gönenç, op. cit. supra note 4 , at $\mathrm{r}_{7}$-I 8 .
} 
favorable. Society is achievement- rather than status-oriented and places a comparatively high valuation on the qualities of initiative and enterprise. Businessmen enjoy adequate prestige and are expected to be independent-minded and adaptable, irrespective of whether the private or the public sector is the scene of their operations. Ministers, bureaucrats, and even parliamentarians are aware of their own limitations, and prepared, in varying degrees, to refrain from meticulous interference in matters of business policy and to protect the managers of public enterprises against undesirable political pressures. By and large, informed public opinion is suspicious of centralization, and seeks the maximum amount of decentralization compatible with consistency of over-all policy. Moreover, there is available a fund of trained and experienced managerial personnel committed to the maintenance of certain socially recognized professional standards. These men enjoy wide opportunities which are by no means confined to the public sector, and therefore have the power to insist, if necessary, on being given conditions of employment which enable them to make the most of their valuable talents.

One could not claim, of course, that things always work out this way in the West, and that the running of public enterprises therefore presents no serious problems. Nevertheless, there is a broad and very distinct contrast to be drawn between these Western norms and those that prevail in the underdeveloped countries, where society tends to be status- rather than achievement-oriented; initiative and enterprise are often regarded with suspicion; the prestige of the businessman is low; the political and administrative authorities regard themselves as omnicompetent; governmental centralization reaches almost pathological proportions; managers are scarce and professionally unfledged; and opportunities for prestigious employment outside the government service are difficult to find. In such countries public enterprise can develop healthily only to the extent that economic development itself modifies social values, changes the prevailing modes of political and bureaucratic behavior, and brings to the fore new types of personnel. But since economic development, as we have seen, depends so much on public enterprise, there appears yet another of those vicious circles which characterize underdevelopment. That there is a way out of it is already proved by the very fact of development. But it is not an easy way out, and certainly cannot be discovered by the mere process of institution-building.

\section{The Cult of "Autonomy"}

To talk about public enterprise principally in terms of institutions is, however, inevitable; and such discussion does not become futile simply because the content of a given institution can vary so significantly from one society to another. Institutions, after all, can provide or deny certain opportunities, and stimulate or discourage certain types of behavior. Thus, the newly created institution itself becomes part of the total socio-political pattern and exercises some modifying effect on previously existing norms. In the specific field of public enterprise, the very fact that the 
agency has been placed at some distance from the ordinary machinery of government and formally endowed with certain "immunities" is bound to have some effect on parliamentary, ministerial, bureaucratic, and managerial attitudes and practices. The government of the underdeveloped country which decides to imitate Western forms of public enterprise is therefore working along the right lines, even though it may be simultaneously over-sanguine in its expectations and. somewhat equivocal in its intentions.

What it needs to beware of is excess of virtue in this respect. In some countries the tendency is to create a new "quasi-autonomous" institution for the fulfillment of almost every new need that becomes apparent. So many public corporations; state companies, and analogous agencies are brought into existence-some for the performance of straight-line governmental functions with only the faintest tinge of the "commercial" about them-that the ministries become reduced, in Mr. Harold Seidman's phrase, to "hollow shells," and there arises a problem of coordination so sizable that even a highly developed administration would be hard put to cope with it. The worst examples of this indiscriminate proliferation of quasi-independent agencies come from Latin America. The International Bank Mission, in its report on Colombia, ${ }^{7}$ distinguished no fewer than twenty-one separate agricultural public corporations of one kind or another. Few of them were functioning well; none appeared to be more than vaguely aware of what the others were doing; and there was no coherent, centrally-decided policy to which they were all supposed to workand even if there had been, no visible means of putting it into effect. A not dissimilar situation was discovered in the Philippines by the Bell Mission. ${ }^{8}$ During the course of a visit to the Eastern Region of Nigeria, this author found that public corporations included a cinema corporation, a sports corporation, a printing corporation, and a corporation for government resthouses. In Turkey, public corporations have been formed to purchase equipment for government offices, to run a pensions fund, and to make loans to local government institutions.

The reasons for this excessive enthusiasm for "autonomy" vary from country to country. In some countries, where political corruption flourishes, it can be a simple matter of "jobs for the boys." Elsewhere, it is often the product of ignorance of sound administrative principles, or of sheer despair as to the likelihood of gettting any serious work out of ordinary government departments which are firmly in the grip of an unimaginative, unenterprising bureaucracy wedded to traditional, timeconsuming routines. Where the last motive applies, it is often found that the remedy is worse than the disease; for the new agencies either quickly acquire the bureaucratic characteristics of the old departments or fall under the domination of private vested interests. Almost any Middle Eastern country will afford examples

\footnotetext{
${ }^{7}$ International Bank for Reconstruction and Development, The Basis of a Development PrograM For ColoniBia 82 (1950).

${ }^{8}$ U.S. Economic Survex Mission to the Philippines, Report to the President of the United StATES 53 (1950).
} 
of the former kind of degeneration, and many Latin American countries examples of the latter kind.

Such situations present "problems" only in the sense that their rectification involves conflict with the vested interests that have built themselves into an administratively irrational structure. There is rarely any difficulty in saying what a government sufficiently devoted to administrative rationality and sufficiently powerful to pursue it should do. But there are other structural issues that cannot be disposed of so "simply." Even if "autonomy" is strictly confined to business-type agencies, and in no way extended beyond its legitimate sphere, the question still arises of what overall structure to give the resultant public sector, and particularly that part of it which is most directly concerned with the stimulation of economic growth.

\section{Organizing Development}

In many parts of the underdeveloped world, one finds the function of stimulation confided, wholly or partly, to institutions known as development corporations. These vary widely in their responsibilities and importance. At one end of the scale, there are comparatively narrow-range bodies designed, for instance, to fill certain gaps in the industrial structure or to stimulate agricultural productivity by making loans to farmers. At the other end, there are bodies whose developmental functions are so comprehensive that virtually the whole of the economy comes within their province.

The latter have received considerable publicity and caused a great deal of controversy. The best known and in some respects the most successful of them is the Chilean Fomento, ${ }^{9}$ which has intervened in almost every sector of the country's economy, by way of creating or financing new enterprises, industrial, agricultural, and commercial. Another well-known example is the now defunct Iraq Development Board, ${ }^{10}$ which, financed with seventy per cent of the country's oil revenues, concentrated its energies on flood control, irrigation, and land reclamation, but also branched out into a great variety of other enterprises and public services.

The advantages of the comprehensive Fomento are obvious. It provides a single agency which can both plan and execute the whole of the government's development program, or at least a very substantial part of it. Coordination, always one of the biggest problems that the governments of underdeveloped countries have to face, is thereby facilitated. Removed some distance from the ordinary governmental machinery yet responsive to political direction, the agency at least begins its activities unhampered by bureaucratic traditions. Its very creation may be regarded by the people of the country concerned as a sign that the government has at last decided to give priority and bring new energy to the task of economic development.

${ }^{\circ}$ Recent material on the Fomento is scarce. The only full-length study in English is Herman Finer, The Chilean Development Corporation (International Labor Organization Studies and Reports, New Series, No. 5, 1947).

${ }^{10}$ See Fahm I. Qubain, The Reconstruction of IraQ: 1950-1957, ch. III (1958). 
"Psychologically," writes Mr. Burgess, the Executive Secretary of the Caribbean Commission, "it becomes a focus for the economic aspirations of the community."11

On the other hand, the disadvantages of this form of organization become apparent rather rapidly. The concentration of planning and execution in the hands of one body always causes difficulty. Too few men appear to be exercising too. much power over the economic life of the community. Either the planning or the executive function tends to be neglected; and the plan itself cannot cover more than a part of the community's economic life. For the Board, even if possessing jurisdiction over the whole range of industry and agriculture, can at best only adviseon matters such as financial and fiscal policy, which clearly cannot be brought within the scope of its own responsibilities unless the government is prepared virtually to abdicate in the Board's favor. To be fully successful, the "one big agency" needs. to become an imperium in imperio, and that is something which most governments: dislike. It also needs to take over at least a very substantial part of the functions. of the economic ministries, and that is something which the ministers concerned, and their civil servants, are very reluctant to countenance. Hence, unless a modus vivendi between the Board and the political authorities can be established, as seems: to have happened in the Chilean case, tensions arise which either destroy the development agency or make short work of the autonomy which is supposed to be its. raison d'être.

In Iraq, where these tensions were acute, the Development Board first lost its autonomy, then its life. The fact that such a large slice of the nation's resources. were "under the control of a few men," writes Dr. Qubain, caused "resentment and even consternation in some political circles." ${ }^{\text {"2 }}$ At the instigation of these critics,. Law 27 of 1953 was passed. This transferred most of the Board's staff to a newlycreated Ministry of Development, gave the Minister the responsibility for theexecution of the Board's projects, and subjected its long-term and annual programs, which were now to be drawn up in much greater detail, to the approval of theCouncil of Ministers and the Majlis. "The original purpose of the Act of r950" was thus frustrated," wrote Lord Salter, "and the Board made dependent for positive: action upon agreement with Ministers changing with Governments."13 After theKassem revolution of $195^{8}$, the Board itself was abolished-although this was probably due more to its associations with the previous regime, and to the unpopularity. of some of the policies that it had pursued, than to any principled opposition to this: type of agency.

Attempts to organize economic development on this institutional pattern have: been rare. The Chilean Fomento is now the one remaining example of a truly general development agency, and even the powers of this body have been considerably curtailed. Most development corporations, even when described as "general," are

\footnotetext{
${ }^{11}$ Burgess, Issues in Industrialization Policy, in Caribben Commission General Secretariat, The: Promotion of Industrial Developarent in the Caribbean I55 (1952).

${ }^{12}$ Id. at 37 .

13 Arthur S. Salter, The Development of Irae, A Plan of Action 97 (I955).
} 
given more limited responsibilities. None of the basic services, such as railways, airways, ports, and electricity enterprises, are brought within the scope of the corporation's jurisdiction, which is confined to the filling of some of the "gaps" in the economy which private enterprise, unaided, appears unlikely to occupy. Like the Iraq Development Board or the Chilean Fomento within their wider spheres of activity, it attempts to do this not only by promoting concerns of its own, with or without private capital participation, but by giving financial support to those private entrepreneurs who show an ambition to set up their own "new and necessary" enterprises. Each of three regions of Nigeria, for example, has a "general" agency of this type. ${ }^{14}$ The Western Region Development Corporation, which the author has studied more thoroughly than either of the other two, establishes industries, either on its own account or in participation with native or foreign private capital; runs plantations; and financially assists small industrialists and peasant farmers. More commonly, however, the developmental function is further subdivided institutionally. Responsibility for industry, for instance, may be separated from responsibility for agriculture; and loan-making may be separated from entrepreneurship. If both of these separations are made, the result will be at least four developmental agencies, concerned respectively with Industrial Development, Industrial Finance, Agricultural Development, and Agricultural Finance.

In fact, of course, the institutional pattern is likely to be far more complex, particularly in a large and populous country, as a result of further specialization. An account of development agencies in India, for instance, would have to cover the constitutions and activities of a vast number of bodies, including several kinds of industrial development and industrial finance agencies, both in the states and at the center; a considerable number of specialized agricultural banks, similarly distributed; a complex collection of bodies concerned with the promotion of small-scale and village industries; and a warehousing organization. It could be, and has been, ${ }^{15}$ argued that the Indians have excessively subdivided those parts of developmental functions which they have confided to such special agencies, and that many of the bodies mentioned overlap and in some cases actually compete with one another. There is some justice in this criticism, for it is true that India tends to go in for over-complex forms of organization; and particularly in the field of industrial and agricultural finance, evidence of unnecessary and harmful duplication of functions is not difficult to discover. But we are not citing India merely as another example of the kind of agency proliferation that has taken place in-say-Colombia or the Philippines; for the Indian Government has at least attempted to give its developmental agencies a rational over-all structure, even if it has not always succeeded. With all her administrative faults, India has probably followed more consistently than any other country the basic principles that ought to govern the establishment of development institutions.

1s See Hanson, Public Enterprise in Nigeria (II. Development Corporations), 37 PUв. ADMIN. 2 I (1959).

${ }^{10}$ See A. H. Hanson, Public Enterprise and Economic Development 169-70, 278 (1959). 
These are: (I) that the corporation or company form of organization should be strictly limited to those institutions which, for business purposes, require the degree of autonomy which it is supposed to confer; (2) that where a new function can be conveniently added to the existing functions of an established agency, this should be preferred to the creation of a new agency; (3) that the attempt should always be made, when subdividing developmental functions, to form a series of "coherent missions," as Paul Appleby calls them, ${ }^{16}$ through the clear delimitation of responsibilities and the avoidance of unnecessary duplication and overlapping. Such principles might appear so obvious as to be hardly worth specifying. Unfortunately, underdeveloped countries tend to honor them in the breach rather than in the observance. Their reassertion, therefore, is not entirely pointless.

\section{Industrial Development Corporations}

Agencies of the development corporation type, while almost universally employed, have an importance that varies widely from one country to another, depending partly on the level of development already reached, partly on the extent to which "pumppriming" operations seem likely to pay off, and partly on the developmental perspectives which the government has adopted. This is particularly so with that most popular of institutions, the Industrial Development Corporation, which plays a key role in the development plans of certain countries but no more than a peripheral one in those of others. The Indian National Industrial Development Corporation, ${ }^{17}$ for instance, was intended to behave as a "gap-filler," although in fact it has become an agency of greater importance than this still current expression would suggest. Pakistan's Industrial Development Corporation (P.I.D.C.), ${ }^{18}$ on the other hand, was. thought of, and has actually become, the country's main agency for industrial development and economic diversification. The reason for this difference is not difficult to discover. A country such as India, which aims at a "socialist pattern of society," envisages the retention of the more important of her industrial enterprises in the public sector, and therefore generally gives them forms of organization that are intended to be permanent. Pakistan, on the other hand, wishes to retain in the public sector as few enterprises as possible, and therefore is far less interested in longterm problems of industrial organization than in the short-term problem of promoting concerns which will be developed as rapidly as possible to the point where they become "ripe" for transfer to private ownership. For this purpose, a wellorganized Industrial Development Corporation is the ideal instrument, and accordingly is given a central rather than a peripheral role in the process of economic growth.

In pursuit of its objectives, the P.I.D.C. has displayed an admirable flexibility

\footnotetext{
${ }^{10}$ See Paul H. Appleby, Re-examination of India's Administrative System with Special Reference to Administration of Government's Industrial and Commercial Enterprises I2, 13 (1956).

${ }^{17}$ See Prakash, Industrial Development Corporations in India and Pakistan, 67 EcoN. J. 40 (I957).

${ }^{18}$ See The Pakistan Industrial Development Corporation, in U.N. Technical Assistance Programme: Public Industrial Management in Asia and the Far East i io (ST/TAO/M/I5) (U.N. Pub. Sales No. 6o.II.H.I).
} 
within the broad limits of procedures it is required to follow, which are thus described: ${ }^{19}$

After carrying out a preliminary survey, for which the Corporation is provided with a revolving fund, a project report is submitted to the Ministries of Industries and Finance and to the Planning Commission. ... An effort is made to associate private capital at the outset. If private participation is not forthcoming at that stage, the project is carried out by the P.I.D.C. After the project is ready, the effort to attract private capital or to sell the mill is renewed. If there is no success even at that stage, then the project is converted into a joint stock company and the shares placed on the market, with the managing agency vested in the P.I.D.C.

As might be expected after some nine years of successful operations, the enterprises in which the P.I.D.C. still retains an interest display a great variety of patterns rof ownership and management. It now holds only Rs. 84 million of a total investment of Rs. 236 million in the fourteen jute mills it has pioneered, twelve of which have been completely transferred to private owners. Likewise, it retains only a Rs. 2.5 million debenture interest in the Nowshera Board Mill and the Nowshera Chemical Works, of which the equities have been sold to a private group. The Lyallpur Superphosphate Plant, on the other hand, continues to be managed and predominantly owned by the P.I.D.C., as only twenty-four per cent of its shares have so far been sold. A further pattern is exemplified by the contractual association between the P.I.D.C. and certain private firms in the management and ownership of enterprises which it has initiated-an association which, although regarded as transitional, will probably be long-term. For the development and operation of the very important Sui 'Gas Transmission Line, for instance, the P.I.D.C. has entered into partnership with the Burmah Oil Company and the Commonwealth Development Finance Company. In some of the promoted industries there is-perhaps rather illogically-direct government participation as well. Thus, the Haripur Rosin and Turpentine Factory is jointly owned by the P.I.D.C., the West Pakistan Government, and the Guest Agency Company.

On the assumption-which is by no means universally accepted-that Pakistan's "free enterprise" perspectives of industrial development are viable, the P.I.D.C. must be regarded, in many respects, as a model institution, which is the reason why it has been selected here for purposes of illustration. If the amount of industrial development it has promoted is not very substantial in relation to Pakistan's needs, the reason is to be found not in any failure on the part of the Corporation to take advantage of its opportunities, but in the country's chronic political instability (at least up to the establishment of General Ayub Khan's dictatorship), the lack (until recently) of adequate central planning machinery, and the low ratio between gross capital formation and gross national income.

The industrial development corporation type of agency has been singled out for mention because it is a form of public enterprise which has a much more important

${ }^{10}$ Id. at II2. 
place in the underdeveloped countries than in the developed ones, and which therefore presents problems for the solution of which the current textbook maxims are not of much help. In establishing public corporations or public companies to run individual industries or public utilities, the underdeveloped countries have a fund of Western experience on which to draw; in setting up industrial development corporations, they are very much more on their own, except to the extent that the record of organizations such as the Italian Institute for Industrial Reconstruction (I.R.I.) ${ }^{20}$ may be regarded as relevant.

\section{Agricultural Agencies}

The underdeveloped countries are even more on their own when it comes to the establishment of special institutions for the development of agriculture. ${ }^{21}$ An industrial development corporation has direct control over the enterprises it initiates: it provides the capital, puts up the buildings, buys the machinery, appoints the managers, and hires the workers. An agricultural development corporation, on the other hand, can be effective only if it succeeds in influencing the behavior of the numerous, scattered small entrepreneurs who constitute its clientèle. Such, at least, is the case in those countries where the greater part of agricultural production is in the hands of peasants, and where the possibilities of establishing publicly-owned estates are limited.

Assistance to agriculture, of course, is nowhere channeled entirely through special agencies. A great deal of the work, such as agricultural extension, can be done more appropriately through the Ministry of Agriculture. But it is often thought advisable to give responsibility for the provision of credit to an Agricultural Bank or Agricultural Development Corporation, in order to increase the supply, to step up the proportion of long- and medium-term as distinct from short term credit, to facilitate supervision of the use of the funds, or to break the stranglehold of the private rural moneylender. In some instances, such an agency is also given the power to sell the peasants equipment, machinery, and tested seeds at low prices and on easy terms of payment. Further tempting extensions of its responsibilities-although by no means always desirable ones-are the giving of advice about agricultural methods and the stimulation of rural cooperatives.

Hence in some underdeveloped countries-usually the smaller ones-we find that almost all services to agriculture other than those provided free of charge by the Ministry, and even some of those which cannot in any sense be made to "pay," are concentrated in the hands of a single Agricultural Bank or Development Corporation, operating through widely distributed local agencies. As with industrial development, however, it is more common to find some degree of institutional

\footnotetext{
${ }^{20}$ See generally Muggia, The Public Corporation in Italy, in Wolfgang Friedmann (ed.), The Public CoRPoration 24I (1954).

22 We still await the publication of a thorough, comparative study of agricultural development institutions. In the meantime, the interested reader may be referred to A. H. Hanson, Public EnTERPRISE AND Economic DevelopMent ch. 9 (1959).
} 
specialization. In Turkey, for instance, there is an Agricultural Bank, responsible for the supply of credit and the supervision of rural credit cooperatives; an Agricultural Equipment Agency, responsible for selling tools and machinery; and an Office of Soil Products, which provides storage facilities and purchases grain and certain other agricultural commodities at fixed prices. ${ }^{22}$ In India, the credit-provision function is itself divided among a number of separate agencies, of which the State Co-operative Banks and the Central Land Mortgage Banks are the most important. ${ }^{23}$

The public provision of credit facilities is almost universal, even if in many cases weakly organized and beneficial mainly to the more substantial farmers who can offer guarantees of repayment. That of marketing facilities is less common, although often of equal or greater importance, particularly in those countries which are heavily dependent upon the export of a narrow range of peasant-produced commodities. Sometimes the requirements can be met by the formation of stateencouraged and state-supervised cooperative marketing societies, comparable in status with the cooperative credit societies with which state Agricultural Banks are frequently associated. Such marketing societies are strongly developed, for instance, in East Africa. More commonly, the need is met by the creation of special state agencies, such as the well-known Produce Marketing Boards in Nigeria and Ghana. These purchase at guaranteed prices periodically readjusted in the light of market prospects, and sell for what they can get. The purchase prices are fixed not only in order to permit the accumulation of reserves and thus to neutralize the impact on the peasant community of fluctuating market conditions, but also to compel the producer, who has no other outlet to the world market, to pay what amounts to a sales tax. The proceeds of the latter are used for a variety of developmental purposes, not necessarily of a rural kind. Here we have an example, paralleled in Burma and Thailand and also-with much more drastic consequences-in China and other Communist countries, of a state trading agency used for purposes of taxation and capital accumulation. This practice has been much critcized, particularly by economists such as Sir George Paish and Professor P. T. Bauer, ${ }^{24}$ but it is not easy to see what alternatives are open to a development-minded government, equipped with only a rudimentary apparatus of direct taxation but anxious to cream off for public purposes a substantial proportion of the agriculturalist's "surplus" income. The danger, of course, is that unless the state has the means of ploughing a good deal of this surplus back into agricultural development, the effect of the agency's operations on the countryside may be a depressing rather than a stimulating one. This, indeed, will be made certain if, in the interests of capital accumulation, the prices paid to the peasants become so low as to deprive them of adequate incentives. The effect of the ill-conceived policies of Argentina's Instituto de Producción e Intercambio on

\footnotetext{
${ }^{29}$ See Hanson, Soysal and Gönenç, op. cit. supra note 4, at 22-24.

${ }^{28}$ Succinct information may be found in India Ministry of Information and Brondcasting, $\Lambda$ Reference Annual ch. 22 (1960).

${ }^{24}$ Bauer \& Paish, The Reduction of Fluctuations in the Incomes of Primary Producers, 62 Econ. J. 750 (1952).
} 
that country's agriculture during the period of the Peronista dictatorship is a classic illustration of this danger. ${ }^{25}$

It will be obvious that state agencies concerned with agriculture of the kind here briefly described are dependent in a peculiarly intimate way on their single point of concentration: the individual farmer. This presents them with a very difficult problem of coordination, which has nowhere been satisfactorily solved. It also means that their operations are so widely spread, and conducted through so many local agents, frequently of poor quality and sometimes of doubtful honesty, that they have great difficulty in maintaining proper control in ensuring that the resources placed at their disposal are not misused. State agencies concerned with agriculture are dependent, furthermore, on responses from their clientèle which, being difficult to gauge, are sometimes entirely miscalculated. None of these difficulties roughen the path of developmental agencies in the industrial field. It is therefore natural for governments to consider the possibilities of extending the "factory" system to the villages themselves, through schemes of publicly-organized cultivation.

These can easily be started on waste lands, if labor and equipment are available; but waste lands, even if they exist, have usually been left waste precisely because they are difficult or unprofitable to cultivate. Moreover, the running of a plantation, managed by public appointees and cultivated by wage labor, usually presents unforeseen and formidable problems. Certain parts of Africa are almost littered with the pathetic ruins of such enterprises. ${ }^{\mathbf{2}}$ Attention is therefore turned to occupied and cultivated lands, with a view to persuading farmers to pool some of their resources and to cultivate in accordance with a production plan. If some central directive agency can be established in the village, or in a group of villages, there will be an effective center of coordination for all the various state agricultural services which, when provided piecemeal for the benefit of individual farmers, so rarely seem to achieve the results that are expected of them. Promotion of cooperative institutions, or of quasi-cooperative institutions such as the sociétés indigènes de prévoyance in the former French colonial territories, is one possible way of accomplishing this aim. But the development of efficient cooperative societies is a lengthy process, and imposed "cooperation" is a contradiction in terms, and usually selfdefeating. Collective farming is another way, but the compulsory collective has proved neither popular nor productive, while the voluntary collective, to judge by Indian experience, is an institution which makes very slow headway, if any at all. These rather discouraging experiences with cooperatives and collectives have suggested a different approach, whereby individual peasant ownership and individual peasant incentives are left undisturbed, but productive techniques, the provision of credit, and the sale of produce are controlled and organized by a local or regional public agency.

\footnotetext{
${ }^{25}$ See Macrae, Argentina's Post-War Experiments, I, The Banker, April I949, p. 23.

${ }^{20} \mathrm{~K}$. D. S. Baldwin, The Niger Agricultural Project (x957), describes one such failure in a manner both scholarly and readable.
} 
So far, institutional arrangements of this kind have had little success in highly populated and old-established rural settlements. They have, however, produced some striking results in agriculturally undeveloped or underdeveloped areas, where peasant "colonists" can be introduced. Even so, experience to date would seem to suggest that success is very largely dependent upon the holding by the public authority of some decisive trump card, such as irrigation water. The most successful of such schemes, Gezira, ${ }^{27}$ was established in a thinly populated area where intensive cultivation depended entirely on the supply of water from a dam and through canals built, maintained, and managed by the authority concerned.

Originally a mixed enterprise, in which the government built the dam and rented the land from its existing owners, and two private companies provided buildings and machinery, supervised operations, and stored and marketed the crop, Gezira is now under the control of a government-appointed Board, with the status of a public corporation. The peasants are tenants, who are responsible for working the land with the assistance of the Board's machines, and for maintaining the minor irrigation canals. They are paid forty per cent of the net annual profits, the remaining sixty per cent being divided between the Board and the government. The tenant cultivates individually, with or without the help of hired labor, and his continued tenure is conditional upon his efficiency.

The success which Gezira has achieved must be partly attributed to conditions not likely to be found in combination elsewhere, e.g., a flat and fertile terrain, easily irrigable from one of the world's greatest rivers; a soil suitable for growing high quality cotton, much demanded on the export market; and a comparatively docile and amenable peasantry, living in a country where political conditions were reasonably stable. But much of it must be put down to good initial planning, the recruitment of a highly skilled and dedicated expatriate managerial personnel, and the imaginative features of the partnership program which, as Dr. Hance has said, "protected the interests of the native, permitted long-term financing of capital expenditure, and secured the services, for a stated period only, of an outside commercial organisation that provided managerial experience and ability for a return sufficient to assure its interest." 28

Superficially similar schemes in formerly French Africa, such as the Office du Niger in Soudan, the Mission d'Amenagement in Senegal, and the Beni-Amir and Beni-Moussa project in Morocco, have also enjoyed some success, although of a less spectacular kind than that achieved by Gezira, which remains unique. ${ }^{20}$ These, too, are all based upon irrigation, which greatly strengthens the hand that supplies it because of its indispensability. On the basis of such experience, it has been held that irrigation is an essential element in the success of such schemes; ${ }^{30}$ but this is

${ }^{27}$ A former manager of this project, Mr. Arthur Gaitskell, has now provided us with an excellent account of it in A. Gaitskell, Gezira, A Story of Development in the Sudan (1959).

${ }^{28}$ Hance, The Gezira, An Example in Development, 44 Geographical Rev. 253, 268-69 (1954).

${ }^{29}$ Some discussion of the conditions making for success or failure are discussed in Hanson, Nile and Niger: Two Agricultural Projects, 38 PuB. Admin. 339 (1960).

${ }^{30}$ See, e.g., East Africa Royal Commission 1953-1955, Report, CMD. No. 9475, at 270-79 (1956). 
probably going too far, as there are examples, from Africa and elsewhere, of promising supervised cultivation projects where irrigation is neither required nor provided. In many of these projects, it is mechanical assistance to the farmer that replaces irrigation as the basis for supervision and control. Many of them, admittedly, have failed, and there is widespread scepticism as to the viability of the remaining ones; but the failures have often been due not to any fault of basic conception, but to inadequate preliminary surveys, excessive haste, wrong attitudes towards the settlers, and bad administration. Such mistakes could have killed Gezira itself, despite the almost unrivalled natural advantages that that scheme enjoyed.

\section{Multi-Purpose Projects}

Some of the schemes we have mentioned, such as Beni-Amir and Beni-Moussa, although predominantly agricultural in conception, have approached the status of multi-purpose projects. ${ }^{31}$ The difference between them and the full-fledged multipurpose project is that the latter emphasizes the generation of electric power as well as the improvement of agriculture, usually covers a much wider area, and does not necessarily involve any centralized organization of agricultural production. Multipurpose projects, with differing degrees of emphasis on flood control, irrigation, navigation, and power generation, are now to be found in many parts of the underdeveloped world. Some of them, such as Damodar, Mahanadi, and Bakhra-Nangal in India, and Gal Oya in Ceylon, have become internationally famous. In all cases, the government has found it necessary to establish special agencies for their management, but these do not invariably follow the pattern set by the Tennessee Valley Authority (TVA), the great prototype which has provided their inspiration. Although all the Indian projects are managed by Boards, only Damodar is run, in the manner of the TVA, by a corporation formally endowed with the usual immunities. The other project Boards are of a "weaker" kind, having no corporate status and consisting mainly of representatives of interested ministries and other agencies, central and state. An interesting discussion of the respective advantages and disadvantages of these alternative types of public authority is contained in Professor Henry Hart's book, New India's Rivers. ${ }^{32}$

Given the necessary resources of capital and labor, the multi-purpose project is in some respects not the excessively difficult undertaking that its somewhat spectacular characteristics might suggest. Admittedly, the basic works, such as the dams, penstocks, power stations, and main canals, usually present their constructors with a whole crop of purely technical problems, but the know-how for the solution of these can always be mobilized from either indigenous or foreign sources. The really difficult administrative and managerial problems come later, after the basic works have been completed-and few underdeveloped countries have as yet solved them

\footnotetext{
${ }^{31}$ See Houston, The Significance of Irrigation in Morocco's Economic Development, i20 GeographicaL J. 3 I 4 (1954).

${ }^{33}$ Henry Cowles Hart, New India's Rivers (I956).
} 
satisfactorily. Relations between the specialized river valley authority and the general organs of state and local government require careful definition and adjustment; peasant farmers have to be shown how to make the best possible use of the newly available irrigation water-and persuaded to pay for it; and complicated costs-andbenefits calculations have to be made. The experience of the TVA is, of course, relevant to the solution of these problems, but its relevance is limited by the dissimilarities of the social and political environment. Even in the running of imitation TVAs, therefore, the underdeveloped countries are very much out on their own.

\section{Finding the Men}

The biggest problem faced by underdeveloped countries in all fields of public enterprise is not structure nor even finance but personnel. In an underdeveloped country one is often compelled not to find the man to fill the job but to find the job that the man can fill. This demands a much greater boldness and originality in job definition and job construction than is necessary in a mature economy, where a clear and continuous relationship has already been established between the personnel-forming and the personnel-using agencies. As this problem is experienced in all fields, and not merely in public enterprise, it hardly warrants any general discussion here. Something should be said, however, about the special issues of top level management which are to some degree peculiar to the public authority.

In a Western public enterprise, the managerial hierarchy is usually crowned by a collective leadership known as a Board, appointed by the political authorities. This may consist of as few as three or as many as twenty members, some of whom may exercise "functional" responsibilities. The Board-type of top management, directly imitated from the private joint stock company, tends to be accepted in Europe if not in America without criticism or discussion, and has been almost universally adopted by the underdeveloped countries for their public enterprises. One may well doubt, however, whether this adoption has been wise; for the case against the Board as stated, for instance, by the Hoover Commission ${ }^{33}$ would seem to have redoubled force in conditions of underdevelopment. The countries with which we are concerned almost invariably find difficulty in making enterprise leadership genuinely collective, and are usually hard put to discover sufficient numbers of adequately-qualified people who are prepared to occupy their time in attendance at Board meetings. Furthermore, in conditions where maximum administrative simplification is desirable, it is not always useful to interpose a body with somewhat vaguely defined powers between operational management and the supervising ministry. It is for these reasons, among others, that Paul Appleby has proposed that the Indian Government, even if it cannot bring itself to the point of abolishing the Boards outright, should at least reduce them to advisory status. ${ }^{34}$ One-man management, with clear lines of

${ }^{33}$ U.S. Commission on the Organzation of the Executive Branch of the Government, The Hoover Commission Report on Federal Business Enterprises 377, 381-82 (1949).

${ }^{34}$ See APPLEBY, op. cit. supra note 16 , at 54,55 . 
responsibility upwards and downwards, would often seem to be the best solutionthe most efficient as well as the most economical use of desperately scarce personnel.

An allied problem is managerial recruitment. A developed country experiences little difficulty in this matter, provided that it is prepared to pay sufficiently attractive salaries. Experienced managers are available, and the only unfamiliar problems they are likely to encounter are those arising from the monstrous size of certain nationalized enterprises (such as the National Coal Board or the British Transport Commission) and from the fact that the political control to which they are subject is liable to be more continuous, more meticulous, and perhaps more capricious than the sort of control that emanates from shareholders' meetings. An underdeveloped country, on the other hand, has to create its own managerial cadres, as there are very few suitable people available for recruitment from the private sector. India is attempting to fill the gap through the establishment of a Public Industrial Management Service, but in the nature of things some years will elapse before this device begins to produce a flow of qualified and experienced candidates for the top-level posts. In the meantime, civil servants have to be used, faute de mieux, as enterprise managers; and the remarkable thing is how well some of them have adapted themselves to this new and unfamiliar role. Unfortunately, this adaptability is not typical, but must be ascribed to the high intellectual capacity and single-minded devotion to the public service of the small group of men at the top of the Indian Administrative Service. Elsewhere, the employment of civil servants to run industries has been not far short of disastrous. In Turkey, for instance, few of them have displayed any sign of the qualities of imagination and initiative necessary for success. Most are quite content to administer their enterprises, woodenly and rigidly, "in accordance with the law," and to accept without protest or criticism the frequently nonsensical orders they receive from the political authorities. It is not always easy to see any obvious and immediate way out of this situation, but the record would seem to suggest that when there is a choice between an experienced civil servant and an administratively inexperienced but well-trained engineer as head of an industrial enterprise, the latter is usually to be preferred. The engineer, like the civil servant, has to learn his enterprise administration, but he brings fewer prejudices to the task and is free from the familiar occupational diseases of the bureaucrat. His training, moreover, gives him a better understanding of the processes of production and predisposes him to think in terms of getting things done rather than of adopting the "correct" attitudes towards his superiors. But there is no formula which an underdeveloped country can use in its search for successful managers. Until it has built up its managerial cadres, it has to search for the necessary talent sometimes in the most unlikely places, and be prepared to experiment and to take chances. There are nevertheless some mistakes which an underdeveloped country ought to be able to avoid without difficulty, if its government is endowed with a modicum of common sense, reasonable honesty, and an ability to resist corrupt and nepotistic pressures. One of the most obvious pitfalls is the practice of making appointments on purely 
political or personal grounds, and of shifting managers from enterprise to enterprise so frequently and capriciously that they never have the chance to become familiar with their jobs. Unfortunately, foolishness of this kind is extremely common.

Another frequent difficulty is the devising of suitable systems of personnel management for public enterprises. In the West, we are generally of the opinion that each enterprise should be allowed to be the exclusive judge of its own needs in this respect; but there is a certain tendency, stronger in some countries than in others, to make recruitment, remuneration, promotion, and conditions of employment approximately the same as in the civil service. In most underdeveloped countries, this tendency is immensely more powerful. The pressure comes partly from the public enterprise employees themselves, who wish to participate in the prestige of recognized government employment and to enjoy the civil servant's security of tenure and regularity of promotion. It also comes from the government itself, which fears that freedom will mean free-and fierce-competition for scarce personnel and open the door to all kinds of corrupt practices. These quite reasonable apprehensions are frequently reinforced by the determination of the old-style bureaucrats to prevent the introduction of new-fangled systems which might conceivably spread to the regular government departments themselves, with deleterious effects on well-worn routines and established expectations. ${ }^{35}$

These factors cannot just be disregarded, and even if they were absent it might still not be possible to dismiss personnel problems as matters for the management. Managers, as we have seen, are usually inexperienced and anxious for guidance. At some point, therefore, a compromise must be reached between the needs of the enterprise and the demands of the public for consistency, regularity, and fairness. There are several ways of achieving this. One is to classify public enterprises functionally, and to devise for each type a broadly conceived personnel system suited to its own operational requirements. This can be done by a special "public enterprises" branch of the Public Service Commission. ${ }^{36}$ Another is to leave the initiative to the enterprises themselves, but to give this branch powers of investigation, advice, and approval. Whichever method is adopted, the important thing is to staff the central controlling agency with people familiar with the problems of enterprise management; for this is a job that run-of-the-mill civil servants, however highly placed, cannot perform.

\section{Conclusion}

In this article, we have deliberately confined ourselves to problems of structure and of personnel, as these are the matters on which some of the most vital and difficult decisions have to be taken. A more complete survey, such as has been attempted elsewhere, ${ }^{37}$ would involve extending the investigation to problems of

${ }^{35}$ See the examples given in Hanson, Public Enterprise in Nigeria, 36 PUB. AdMrN. 366 (1958).

${ }^{36}$ At the time of writing, the Turkish Government is considering this solution.

${ }^{37}$ See generally my work cited supra note 15. 
finance, pricing policy, and relations between public enterprises and the political authorities. These are obviously of the highest importance, but on the whole more written about and better understood. Enough has been said, we hope, to indicate that in the establishing and running of public enterprises, the underdeveloped countries are confronted with problems which, although in some respect analogous to those experienced elsewhere, need to be specially studied in the context of underdevelopment. 